\title{
How Tanzania Can Escape a Poverty Trap: Lesson from China
}

\author{
Migeto Zakaria \\ PhD student: Minzu university of China
}

\begin{abstract}
Today, the success story of china's great leap from weak socialist state to hegemonic world producer and great USA and Africans countries creditor astonishes a lot of scholars. In 1980 china's GDP per capital was only 193 US dollar which similar that of African countries like chad and Malawi and Asian like Bangladesh. Translating this GDP per capital, at that time china's average food consumption fell below basic nutritional standards. Chinese people did not eat more or better food prior 1980s. Politically, China's CCP regime was extremely dictatorial ushered two major economic upheavals; the so called the great leap forward of 1958-1961 where to accelerate economic production by political demand china enacted a policy scheme which was a disaster. Thirty years later china became the world's second economies and her GDP grew from USD 193 to USD 6,091 by 2012 leaving other countries like chad, Malawi and Bangladeshi far behind. What happened during this thirty years of china's great leap and what lesson does it give to African countries like Tanzania? This article tries to see some useful hints that made china great as she is now and what lesson can African countries like Tanzania learn from this transformation "great leap process". The reason beyond this success story owes not to good governance as a prelude to development nor history as a factor for underdevelopment, coevolution between the state and society was a vital force. The article provides a suggestion on Tanzania to develop must first have industrial and agriculture societal based policies. This article also based solely on Yuen Yuen Ang literature on how china escaped poverty trap.
\end{abstract}

DOI: $10.7176 / \mathrm{JPID} / 54-01$

Publication date:May $31^{\text {st }} 2020$

\section{Introduction}

The author of how china escaped poverty trap started writing his book by providing parable of a pauper who visited two finance advisers for advice. The pauper was not only broke but poorly educated as well. The first finance adviser urges the pauper to earn the first pay check, once earned the first paycheck the circumstances will improve and will eventually escape poverty trap. The second financial adviser had slightly different advice, urged the pauper to start doing like his other rich clients do, attend college and move to safe town and buy health insurance. You can only escape poverty by first creating the prerequisites for wealthy.

However the two financial "gurus" provided no clue on how to both neither how earn a first paycheck nor sustain a stable income and how to attain this "prerequisite for wealth". This parable reflects the really world their worlds are experiencing and china experienced thirty years ago. All wealthy capitalist economies feature institutions of good governances such as protection of private property right, professional bureaucracies, modern courts, formal accountability, and pluralistic participation which all seems necessary for successful markets yet attaining this also appears to depend of the level of economic wealthy. The question remains how can poor weak countries like Tanzania escape poverty trap? Which comes first in development; economic growth or good governance?

Modernization theory holds that as countries grow rich, the emerging middle class will demand accountability and protection of individual rights, leading eventually to capitalist democracies. Some modernist holds when countries succeed in modernizing public administration and eradication corruption they will become wealthy. Reflecting to the pauper story the question is how this poor countries can achieve economic growth the answer is still vague.

Second argument is a causal claim which holds that good governance can lead to economic growth. Most of western countries hold this claim by pushing developing African countries to adopt western democracies as will lead to growth. The argument is based on premises that it is to good governance right before market can grow. Arguments holds all the prosperous western markets holds the premises of good democracy, if a country will hold this principles growth is inevitable. But the question remain on how will country like Tanzania out of a blue attain or develop good governance let along maintain it. It is widely observed these developing courtiers developed modern courts system, holds democratic elections, and have written laws in books but have licked professional judges and both government incumbents and common citizens have abused elections and continuously broken laws.

However there is a third school of thought who holds the history as a determine factor for development and underdevelopment of developing countries. By following a path of dependence theory several scholars point out nature of colonization as the source of development and underdevelopment of developing states. In why nations fail Acemomoglu and Robinson trace the development and underdevelopment of North American which was under British colonization and Latin America by the Spanish. The argument point out the supportive and of English 
colonizers who founded settlement and equal opportunity hence paved the great start of future capitalist success. While the Spanish ran a exploitative and predatorily regime that made Latin America as it is now. This school of think has great weakness as it failed to point out why some states which were under the British administration still poor too while other developed? Kenya and even Tanzania herself was under British colonization but still struggling.

The theoretical underpinning of this study base on premises that in order for development to happen developing countries don't need good governance to get rid of poverty trap, the principles of good governances are however vital on preserving markets, development does it need economic growth to happen even if it does, how these poor developing countries like Tanzania can achieve that first step of economic development? The study shade light on china's coevolution and that, the first step of development is to harness normatively "weak" institutions to kick-start markets.

This article intends to briefly point out how china escaped poverty and what lesson other developing countries like Tanzania can learn from this success story. It will however show a brief Tanzania development trajectory since independence and theories of poverty trap web.

\section{The argument behind how development actually happened in china}

In her book how china escaped the poverty trap and made the great leap from barren communist political economy into the middle income, capitalist dynamo that it is today, Ang based her analysis on basis that development is coevolutionary process. The argument defies the conception that it is either institution of good governance so keenly proffered to developing countries today to launch market or it is growth that enables good governance and definitely not predetermined history.

Before markets opened in 1978, China was an impoverished planned economy governed by a Maoist bureaucracy. In just three decades it evolved into the world's second-largest economy and is today guided by highly entrepreneurial bureaucrats. In How China Escaped the Poverty Trap, Yuen Yuen Ang explains this astonishing metamorphosis. Rather than insist that either strong institutions of good governance foster markets or that growth enables good governance, Ang lays out a new, dynamic framework for understanding development broadly. Successful development, she contends, is a coevolutionary process in which markets and governments mutually adapt.

By mapping this coevolution, Ang reveals a startling conclusion: poor and weak countries can escape the poverty trap by first harnessing weak institutions - features that defy norms of good governance - to build markets. Further, she stresses that adaptive processes, though essential for development, do not automatically occur. Highlighting three universal roadblocks to adaptation, Ang identifies how Chinese reformers crafted enabling conditions for effective improvisation.

The argument on how development can actually happen she argued that, states and market interact and adapt to each other, changing mutually over time. In terms of china, it provides a rich experience and illustration of coevolutionary process of development, according to her, so does western societies too followed a coevolutionary pattern. This argument is elaborated by mapping the concept of coevolutionary. This argument of coevolutionary between markets and states is has the following framework.

The first framework of coevolution is build markets with weak institutions. According to her analysis framework, institutions, strategies, and state capacities that promote growth vary over the course of development, among countries and even among localities within countries. She argues, practices and features that defy norms of good governance normally view as weak institutions are paradoxically the raw materials for building markets when none exist. Concluded by arguing that good and strong institution found in wealthy economies are for preserving exist markets.

The second framework of coevolutionary argument is to create a right condition for adaptation. History is not destiny, however past encounters determine the starting point; any given legacy may be reshaped for destructive or constructive ends. Instead of attribution national successes and failure only to history and geography, she emphasized on the effort of the reformers to foster improvisations among ground level agents, such that they may utilize existing resources to tackle the problem of poor, and they by turn the typical problem if underdevelopment into the solutions to development. Improvisation does not usually succeed at a first take, it often fails. Instead of dispensing on mimic, promotion of innovation and embrace experimentation are key concepts for adaptation and improvisation.

There are three distinct patterns to China's take off: the changes made by the state are broad, bold and uneven. Broad in that the state makes changes across the whole economy: she has little time for Dani Rodrik's attempts to identify specific bottlenecks and tackle them one at a time - that is thinking about the economy as a complicated, rather than a complex, system. Bold in that when the state changes direction, it does so big time, and the whole country, or at least its 50 million civil servants, jump and do whatever it takes to achieve the new goals. Uneven because the changes play out differently according to time and place within China, and the leadership is happy with that. 
Secondly, to explore China through the lens of complexity, she unpacks three signature processes of coevolution, summarized in the graphic:

Variation: how does the system throw up alternatives and options to deal with particular problems?

Selection: how does it select among the variants to form new combinations?

Niche Creation: how does it craft new, distinct and valuable roles within the system?

China's answer to the variation question is a fascinating one. The phrase 'mono party' conjures up an impression of a regime intent on command and control. An autocracy like China has plenty of red and black lines (don'ts and dos), of course, but what Ang reveals is a third tier - deliberate 'directed improvisation'-a 'paradoxical mixture of top-down direction and bottom-up improvisation'. The state sets broad, and often very vague, parameters and then it is up to officials to improvise within them, often coming up with solutions and innovations that astonish Beijing. This conception is as of Peter Evans on the technocracy of developmental states where there is state society synergy "embedded autonomy".

She paints a picture of millions of study groups of civil servants poring over the latest Delphic utterances from the Central Committee (e.g. 'socialism with Chinese characteristics'), trying to work out what they can get away with, then entrepreneurially beavering away in responses. Her argument has a partial explanation of why the vague rhetoric of leaders has such a galvanizing effect on officials - she doesn't touch on the stick - the potentially lethal consequences of getting things wrong/overstepping the new line.

But she graphically demonstrates the carrot - officials on misery wages (the state did not have the capacity to pay properly) were allowed/ encouraged to take a cut of any economic activity they could generate. Corruption in the form of 'profit-sharing' by officials was an integral part of the model (Ang even worries that the current crackdown could hamper further progress). More broadly the state operates a decentralized 'franchising mode', with local government at various levels keeping much of the proceeds of growth.

She shows that China did not follow the East Asian tiger route of highly technocratic 'developmental states' 'picking winners', not least because of a chronic shortage of technocrats - under Mao, anyone showing signs of technical expertise was branded a capitalist running dog (a term we really need to start using again). Instead primitive accumulation - the first steps on the road to take off - built on what China had in abundance: social networks. Every department and senior official was required to hustle for investment from friends, relatives and contacts, and incentivized with juicy bonuses.

The problem of thus arguments is one thing. Developing countries cannot use china's model of great leap due to its autocratic system of governance. Am not saying autocratic system doesn't work, no; it worked in china perfects, but will never work in Tanzania due to the fact that Tanzania is a democratic nations run by different people with different development destinations and goals. Unless Tanzania tries to utilize its partial democratic in "some ways" development will never happens.

\section{How China's great leap happened?}

In 1980 China's GDP was US Dollar 193 which similar that of African countries like chad and Malawi and Asian like Bangladesh. Translating this GDP per capital, at that time china's average food consumption fell below basic nutritional standards. Chinese people did not eat more or better food prior 1980s. Politically, China's CCP regime was extremely dictatorial ushered two major economic upheavals; that of so called the great leap forward of 19581961 where to accelerate economic production by political demand china enacted a policy scheme which was a disaster (Ang 2016).

Thirty five years later china has become the world's second largest economy, the world's exporter and America's largest creditor, and her GDP jumped up to thirty fold to USD 6,091. So how did this great leap happen? The answer is little complicated, it is neither good governance nor development comes first for social development and escaping poverty trap, surely history is not the destiny of these developing countries either. According to (Ang 2016) coevolution is how china managed to make the great leap to become what it is now. In understanding china's coevolution the writer of the book how china escaped poverty trap chose one of Poor County in Jiangxi province. In terms of GDP Jiangxi ranks among the poorest provinces hence the situation of Jiangxi is a roughly representative of that's in china's poorer inland region and of course the basic bureaucratic setting and structure of local government is nearly identical throughout china.

Coevolution in this article it meant states and markets interact and adapt to each other changing mutually over time. Poor and weak societies in general can escape poverty trap by building markets with weak institution they have. Institutions, strategies and state capacities that promote growth vary of course of development, among countries and even among localities with countries. Poor countries possess abundant of so called weak institutions. Examples of weak institution in this article are government regulations, industrial promotion policies, incentives for petty fee extraction, campaign style, fusion of public and private interests and poverty eradications institutions. Normally a lot of scholars believe that to get out of poverty trap is just to replace such weak institution with the strong one like that on the west. But it more than that, there is a potential development stimulus lies hidden behind these weak institutions. 
In the process of tracing the coevolution process is best to go down to county level and see how scholars have been debating the great leap. Glorious County began as a poor, agrarian, and closed economy run by Maoist bureaucracy and lacking the core capabilities of conventional growth promoting states. How this county did made the leap forward? According to conventional wisdom, this transition might occur through two contrasting linear path. The argument is that the government must first replace the preexisting Maoist bureaucracy with brand new fleet of professional agencies and follow the best practice of Weberian administration. According to the argument it is economic growth that leads to improved governance not the way around. These county needs to inject massive FDI that later it will be able to create professional agencies.

However this county did not first get good governance before pursuing economic growth. In fact, glorious county pulled itself up using its own resources it has; it did not rely on handout from central government or foreign direct investments. At the beginning under Mao, cadres perceived to have any capitalist dealing were punished therefore it was impossible for county leaders to have any connection with imperialist investors. This county government improvised development strategies. However later after Mao's rule and under Deng Xiaoping the central government gave green light for local government to pursue external investments. Following this government support policy on pursue of external investments, this county government made changes to capitalize on this new policy opportunity.

To demonstrate the figure above, did China's some of coastal cities escape poverty by first establishing private property rights, eradicating corruption, and hiring technocrats? No, they did not. Instead, local governments dispatched all civil servants to recruit investors using their personal relationships, like a group of sales teams. Officials received a personal cut of investments made, allowing them to legitimately reward themselves, while formal salaries were kept low.

Upon capitalizing marketing opening policy and attracting external investors, county leader thought of two options. The alternative was either to assign one agency to specialize in attracting investors or get all agencies to seek investment all together to maximize the chances of getting a hit. Just like the japans MITI, the government chose to build competent and specialized team of competent officers. These technocrats/ experts wound draw up macro-economic plans, design county wide economic policies and seek investments opportunities that were in line with the county's long term developmental vision. Being poor and weak in china influenced the selection of bureaucratic in two significant ways. First Poor County is hungry of external investors of all kind, and secondly Poor County lacked experienced and well competent investment incumbent. Although glorious county lacked sophisticated know how in market management, it had one key abundant resource: personal networks. This local government really worked hand in hand with the society and it new how important to have trust and work together. It should be a state society synergy as peter evens suggested for development to happen. If people cannot trust each other or work together, then improving the material conditions of life is an uphill battle (Peter Evans 1997).

An average county had more than twenty thousand cadres, each of whom had family members, and even overseas relatives, who could supply capital and raw materials and provide a demand for manufactured goods. What a poor rural lacked in terms of modern markets and technical expertise could be compensated by strong personal ties and the effective power of such ties. All this together provided a beehive for startup development in county level.

After attractive the first wave of investors the county government were no longer hungry, it started to be picky on who to allow to invest on the county government. It started to attract only quality investors and to sustain growth. In other words the investment criteria changed as a result of economic change. At some point some personal networks had been exhausted and could no longer function well. In this environment a new success criteria that's a pursuit of quality investments rather from personal connection was in motion, therefore motivated the selection of new bureaucratic trait (a professional mode of investment promotion). Policy makers, businesses, as market grew; mature entrepreneurs made decision not based on personal ties any more. To supply these conditions the county government would require specialized economic agencies to plan and execute investment policies, this time placing emphasize of industrial coordination and selective investment promotion. To put succinctly clear the county government made significant invest changes through bureaucratic reforms.it redefined bureaucratic roles, remove en masse investments targets, and recruit more professionals.

Just to be clear up to this stage of development where societies and counties were developing fast, but the government were no close that of Weberian good governance. Corruption was still rampant and politician haggled for speed money. Speed money means payment to bypass red tape and speed up administrative procuresses.

The emergence of urban and industrial economies changed the direction of greed among political elites who controlled access to markets. For them it would be foolish to repel businesses through arbitrary extractive practices when forging partnerships with a select group of capitalist presented a far more beneficial alternative. Working hand in hand with businesses ensured continued county development hence less poverty trap on local level. During this great leap, as growth unfolds government changes too. The great leap from poor and backwards to rich and modern political economy bureaucracy involves not only were professionalized but there were fundament shift on nature of corruption. 


\section{Lesson learned}

Studying Chinese development from coevolution paradigm provided significant important lessons. It is not good governance that leads to capitalist growth, infect State intervention sometimes destroys developmentally promising social networks and undermines developmentally useful social norms (Peter Evans 1997). At the beginning china used the only meager resources it had to jump start economic growth. It was not massive economic investment neither from central government or foreign direct and certainly not planners from Beijing imposed comprehensive interventions on investments. It was a bottom up initiatives of local governments in mobilizing existing resources that lured an initial wave of investors.

We also learned that higher income led to bureaucratic professionalization not only financial resources grew but also because of preference of policy makers changed. When poor the goal of local leaders was simply to eat what was on the table that whatever kind and quality of investment available but started to develop and become stronger they aspired to eat better food. Elite preference changes as the economy changes. In this since it is not better governance than will lead to economic growth rather innate local initiatives and connections. Modernization theory argued that growth is a prelude for capitalist development hence good governments, but didn't provide basis on how the growth will really start (Ang 2016).

There was synergy on the basis that, entire county bureaucracy, both elites and non-elites were mobilized to promote growth, and were all personally vested in the process of market building. These actors creatively reconfigured existing informal norms and communist institutions for the purpose of constricting capitalism from the ground up. The idea of "synergy" implies that civic engagement strengthens state institutions, and effective state institutions create an environment in which civic engagement is more likely to thrive. The actions of public agencies facilitate forging norms of trust and networks of civic engagement among ordinary citizens and using these norms and networks for developmental ends. Engaged citizens are a source of discipline and information for public agencies, as well as on-the-ground assistance in the implementation of public projects (Peter Evans 1997).

Even though their initial strategies defies Weberian conception, they worked spectacularly well for take of stage of development. Therefore there are three causal sequences that accelerated development in glorious county of Jiangxi. What county government did was to harness preexisting weak institutions to build markets (convert and combine personal connections and communist campaign style enforcement into resources for investment promotion) the automatically emerging market stimulated strong institutions (on set of early growth and chaotic markets spurred leaders to rethink the focus of development and readapt the bureaucracy accordingly). Then this strong institutions preserved markets (emergence of professional bureaucratic traits and replacements of petty corruption with institutionalized corruption provided a predictable basis for advanced market) (Ang 2016).

In summing this up, even with in same geographical location the particular institutions and strategies that promote growth vary over the course of development with changing priorities and income levels. In this matter improvisation is very important, as we also learned that the effect of initial unorthodox measures such as the beehive campaign (a slogan meant let all members join in courting investments) did not work equally and at the same time across region. Local governments were allowed to improvise by not taking development strategies from Beijing rather Beijing gave development directions but local country improvised the strategies to fit the local geographical requirements and needs. Geography plays a significant role determining any locales starting point's opportunities. New opportunity may rise or declines neighboring economies evolves; improvisation is the key to adapt the situation (Ang 2016).

The underlining question is what allowed coevolutionary processes of change to proceed in the glorious county? The answer in there is a plenty of improvisation involved. First the central government did not dictate which specific bureaucratic practices and economic strategies should be followed and various junctures on county's development plans.

\section{What Tanzania should we not learn from china}

Today China alone accounts for three-quarters of reduction in poverty around the world. Within a single generation, china has morphed from a socialist backwater, poorer than Bangladesh and Chad in 1980, into the world's secondlargest economy. True, there remains tremendous inequality in China. Many have not benefited from prosperity. Still, its past growth has lifted 700 million people out of extreme poverty, which is no mean feat.

The global community has been either reluctant or unable to take lessons from China's success for one striking reason. One big reason for the west not to take china as a model and good example to other developing countries like Tanzania is its autocracy model. The ruling party forbids national elections. Individual rights are not protected by law. China fails many standards of good governance. Hence, it is set aside as an anomaly: conspicuous but not recommendable. In ground it is even impossible for Tanzania to use or learn china's model of development because china's autocratic government was impetus for development. Tanzania like many African countries has copied the so called "democracy" where some opposition parties are used as western puppets to slowdown development in favor of exploitative foreign powers. However clearly, it would be a shame to dismiss China's experience entirely. To take lessons from it, however, we must discern what to learn and what not to learn. In addition. Developing 
countries should not adopt China's autocratic rule. Autocracies are good at getting things done, once their leaders decide on certain goals. But if such goals are misguided, as was China under Mao Zedong's rule, the results can be disastrous.

Developing countries also should not copy the Chinese leadership's futile attempts at exerting precise control, such as over stock markets or the internet. Such control often backfires, as seen in the billions of dollars lost by the government to save the stock market last summer. If Tanzania tries to dictate stock markets and internets it will steer public outcry and even unrest since it has "partial western democracy" unlike china where central governments order is "THE WORD".

So what is there to learn from China? Beneath the veneer of autocratic rule lies tremendous improvisation and creativity, often within the party-state and at the grassroots level of society. Bottom-up improvisation-not central planning - has been the driver of China's escape from the poverty trap. Contrary to popular views of China as a monolithic dictatorship, it is one of the world's most decentralized administrations. Leaders in Beijing sketch out grand visions, but the routine work of development is done at a local level, where the government interacts directly with investors and people. One remarkable feature of this highly localized model is the eagerness of local officials and entrepreneurs to kick-start markets using what appears to be the "wrong" method. To get this point, we must review history. Looking back at the past of wealthy coastal cities in China today, did they escape poverty by first establishing formal property rights, eradicating corruption, and hiring technocratic officials, like in Singapore?

They did not follow the NIC model like Singapore; Instead, these places launched development by making best use of their resources at the time: communist officials with family and friends. Hence, entire bureaucracies were dispatched like bees in eager search for investors. Then as local economies grew, the goals of development evolved: from desiring any investor to quality investors only. These changes pushed local governments to recruit professionals and formally protect property. To be more precisely open, the template of "good governance," championed by the World Bank, was not the cause of market emergence, but rather its outcome. Good governance serves to preserve markets that already exist. Building new markets, however, requires improvising with existing features of poor societies, which often look weak, wrong, or even corrupt.

To be clear, the lesson here is not that other countries should copy the exact things that China did. That's foolish. My point is that poor societies must leverage their own unique features to jump-start development, rather than import best practices from the wealthy. Consider other examples beyond China. In Nigeria, local filmmakers exploited piracy as a distribution channel, enabling their films to sell rapidly in an otherwise hostile terrain. In Bangladesh, dense informal networks in villages became the basis for Bangladeshi social entrepreneur Muhammad Yunus' successful experiment at micro-financing. Seizing advantage of poor public transportation and weak regulations, hail-a-ride businesses are booming in Indonesia.

Stories of failure among the poor are plentiful. It is easy to argue that bad institutions, corruption, and weak governments cause poor countries to fail. But what we really need to understand is how to create success under adverse conditions, how to turn the problems of developing nations into potential solutions, and how to leverage local knowledge to meet challenges.

Conclusively, Ang concludes by arguing that, China is a textbook case. Its experience must not and cannot be copied wholesale, just as the experience of any country - including the United States - should not be blindly replicated elsewhere.

\section{Tanzania economic trajectory.}

Before perusing of china's great leap perhaps it better first to see Tanzania's development trajectories since independence. Just like china at the beginning where political leadership determined this three epoch's development. Upon tracing social development and its influence, the paper will base on three epochs of Tanzania economic development. Descriptions on these three epochs are based on economic policy and political leadership that shaped economic development. On the next three epoch we can see what wrong was and is Tanzania doing makes her to stick in poverty trap.

Economic development in 1961 - 1967

Before independence in 1961, Tanganyika now the so called Tanzania, after 1964 Tanganyika and Zanzibar union was first under Germany colonial masters 1884-1918, later became under British colonial rule to 1961. Colonization of Tanzania just like any other African countries colonization was economic decision of colonialists. It was a result of dividing African among imperialists nationals for economic exploitation that is obtain raw material from Africa. Berlin conference 1884-1885 was the meeting for imperial nationals aimed at dividing Africa for economic reasons.

The process of colonization of African continent meant that African countries' economies were tied up with their imperialist masters. Colonialism made a deep impact on the economic development and change in the colonized countries. The general economic motives of colonization were acquisition of raw materials for economic development in the colonial countries. Colonialism brought cash economy with it. Colonies, including Tanganyika, 
became suppliers of raw materials like minerals and agricultural commodities (cash crops) and buyers of processed manufactured goods (from colonial masters). The economic structure that was established by the colonial powers has had many and far-reaching implications almost fifty years after the independence of many African countries. (Rodney 1972) on his book how Europe underdeveloped Africa talked on how exportation of raw material and importation of finished goods killed the spirit of African industrial development.

Tanzania got its independence in 1961; however it was a political independence rather economical. The economy continued to be mainly within the hands of the British colonial masters and Asian businessmen, mainly Arabs and Indians. Industries, plantations, banks, mines and relatively large commercial activities continued to be under the British and Asians. The economy continued to be basically a market-oriented one with private sector capitalism dominating (Ngowi 2009) Tanzanians never benefited from the fruits of independence and their livelihoods' risk were at large.

As first five-year plan Tanganyika's government made huge efforts on policy and program which depended on foreign investments to support massive, capital-intensive industrialization (Kaiser1996). The political decision just after independence therefore was to continue with the capitalist mode of production inherited from colonial masters. It can be argued therefore that the relationship between political actors (TANU leadership) and economic policy was one in which the leaders followed more or less the policies inherited from colonial masters. The interests of colonialists were continued in this epoch (Ngowi 2009). One of the common huge mistakes that Tanzania made was the continuing of the policy from colonial imperialist policy. These policies aimed at exploiting the peripherals that's African countries with the sole purposes of feeding the center i.e. imperialists from Europe.

As anticipated from the key tenets of capitalism that include private ownership of major means of production and market oriented economic practices, a number of imbalances were observed by the mid-1960s. The political decision to embrace capitalism after independence led to a number of market failures as the state did NOT intervene in the economy. The expected "fruits" of independence were not realized by the majority of people. Poverty continued to dominate and the common man and woman did not see the benefits of independence from economic point of view, social livelihood continued to be at risk. Some scholars say it worsened (Rodney 1972). Tanganyika's continued to toil for the same colonial masters they had toiled for before independence. This unfortunate situation was observed by the political leaders of the day. A new political decision to address the imbalances brought by capitalism was made. The decision has had many and far-reaching impacts in the economic development and change in the country's economic development and change process. This is discussed in the section on the second epoch of the country's development and change process Ngowi (2009).

Economic development in 1967 - mid 1980s

It was at this epoch Tanzania government decided to own its economy instead of being under few individual imperialistic national like on the first phase demonstrated. By 1967 Tanzania's political and economic model of development took a huge and rapid turn. This was a result of a political decision that gave birth to Arusha Declaration that was proclaimed in this year in Arusha. This was a blueprint policy which was expressing that Tanzania would follow the left... Ujamaa (This is a kind of African socialism) policy. The policy implied that the country would be following socialist oriented economic and political policies that meant all tenets of capitalist were terminated in favor of socialism model of development. The capitalist, private sector market-led economy that was inherited from the colonial power at independence was replaced by state owned, centrally planned and controlled economy. All the major means of production in the country (industries, plantations, commerce, mines etc.) were nationalized and put into government hands. The state became the major owner, controller and manager of the state owned enterprises (SOEs). In other words you call this state sponsored capitalism.

Good-intentioned as it might have been, the political decision to practice centrally planned economy with public ownership and government intervention did not work well. The nationalization of the productive sectors of the economy has been among the major reasons for poor economic development in Tanzania. The hither-to private sector owned and managed enterprises became public enterprises. The government controlled major means of productions, that means price were arranged, market were anticipated by government. Since Arusha declaration in 1967, the government has attempted to move from the export of raw material to export of processed goods. According to Robert Bates book markets and states in tropical Africa, Tanzania determined to continue with its industrial development so much to the extent of buying raw material from farmers cheaply to feed the ailing industries.

Like china Mao's ten years of madness (1966-1976) which was his effort to accelerate economic production by political command that led to mass starvation and loss of life of thirty million peoples, Tanzania's government made a same political decision to boost its economy, therefore the government initiated policies which were oppressive to farmers in favor of industrial (yuen yuen ang 2016). At that time, coffee growers in Tanzania sold their coffee to crop authority which was government institution acted as government-sponsored monopsony. There was only one buyer. Example in 1975 and 1976 coffee growers in Tanzania sold their coffee at $6.32 \mathrm{Tsh}$ per kg while price at world market stood at $14.85 \mathrm{Tsh}$ per $\mathrm{kg}$. Tanzania government at this epoch was relocating resources from farmers to industries through pricing policy, export taxes and pricing taxes. Even though by then the 
majorities of Tanzania's livelihoods depended on farming the government were willing to sacrifice interests of farmers for development of local industries (Bates2014).

Since the government favored this local industries, They were prone to inadequate managerial and technical skills; embezzlement; capacity under-utilization; reliance on government subsidies; non-payment of taxes; overemploying; protected from imports; and monopolistic in nature. As a result they became loss-making entities that depended on government subsidies for their survival. As public enterprises, they did not pay tax to their owner either. It is not surprising therefore that most of these SOEs came to a virtual verge of collapse. They became heavily indebted and employees were now and then sent into long unpaid leaves (Ngowi2009).

Public administration sector with a sizeable contribution from agriculture and manufacturing/ industries made it possible for Tanzania economy to increase its GDP at 0.7 per annum (Levin 2001). Exports stagnated due to the policy environment that was hostile for exports as government either banned or heavily taxed exported raw material. Government had control on marketing of goods and services. Inefficiencies drove down producer prices and there was high effective protection of the import-substituting industrial sector. Trade controls, instead of exchange rate adjustment, were used as a means of adjusting to external shocks. Suppression of private business limited opportunities for entrepreneurship (Ngowi2009).

This epoch has its cons, as social capital increase due to government subsidy in several sectors. Despite the fact that some of economic policies under Nyerere resulted into a reduction in productivity in some sectors, his focus on human development and self-reliance did bring some success in other areas of socioeconomic indicators as indicated by Human Development Index (HDI). Tanzania subsidized up to 100 percent for some social services. Education (from primary to tertiary level), health and water were among such services. One good example is the illiteracy rate which was 90 per cent in 1960, it declined to the lowest levels in the mid-80s to $10 \%$ and figures for 2000-2007 periods indicate that the rate has been estimated as 28\%. In the so-called knowledge based economy world of today, illiteracy is one of severest constraints of socioeconomic development because illiteracy reduces chances of an individual exploring one's God-given potential as national competitiveness (Kamuzora 2009). Looking at the role of these services for economic development, especially education, the epoch should be seen as an era for investment in human capital. The investments in social services that took place at this epoch are among the current and future driving forces of economic development and change in Tanzania.

The mid-1980s economic development to date

In this epoch, once again Tanzania's political choice has been to embrace the capitalist economy which is marketoriented and private sector led. The relatively free interplay of the market forces of supply and demand is now the major defining characteristic of the country's economic development and change. It was a reform era that made total change of Ujamaa policy to embrace capitalism mode of development.

This epoch is characterized with major reforms. Among include privatization of the SOE that were nationalized in the aftermath of the 1967 Arusha Declaration; relaxation of entry restrictions in virtually all economic sectors; deregulation in various industries; abolition of price controls; independence of the central bank; elimination of import licensing; removal of foreign exchange, exchange rate- and interest rate controls; easing of controls over mergers and acquisitions (M\&As); public sector service reform, and political reforms in form of allowing multiparty democracy. All of the above reform elements that are in place in Tanzania today would not have been possible without the 1985 political decision to depart from the 1967 political decision to embrace Marxist-Leninist political and economic philosophical orientation. The reforms are having profound impact in the economic development and change in Tanzania (Ngowi 2009).

In this epoch foreign direct investments were highly embraced. A lot of countries have acknowledged the importance of FDI entries for their economic growth, poverty alleviation and development in general. FDIs are widely known to be crucial engines of growth especially in the developing countries. It is recognized that FDIs are capable of creating employment, transferring technology, increasing government revenues and contribute positively to the capital formation process of host economies (Ngowi; 2005). As a result of these and other potentially positive roles that FDIs can play in host economies many countries wish to attract more FDIs. FDI benefits include development of ailing industries, direct and indirect and often better paying employment opportunities therefore better livelihood, reducing investment capital gap, introducing up to date and state of the art technologies; superior managerial, leadership and marketing skills; increasing government revenues through privatization proceeds, fees, concessions, dividends on profits, and taxes; supporting community social development projects; forward and backward linkages with the rest of the economy and generally increasing to the supply side of quantity and quality of goods and services in the economy.

At this epoch the government of Tanzania was like what (Ang 2016) how china escaped poverty trap analyzed the work of Harrod-Domar noted growth comes from capital investments, and this capital investments can be secured through foreign direct investments, these FDI can jump start the economy. Even though the national GDP is growing but this kind of economic aid is worsening the economy and Tanzania is still struggling to get rid of poverty trap as the majority common Tanzania still trapped in poverty web. On top of that, industrialization failed miserably as the state failed to implement its industrial zones plans. Initiating special economic zones is not a 
recent move in Tanzania. Following some failed attempts at establishing SEZs in Tanzania in the 1990s (Mudida 2006), Tanzania officially established SEZs under the Special Economic Zones Act 2006 (as amended by the Economic Zones laws (Miscellaneous Amendments Act 2011)) with the view to achieving what was known as the Mini-Tiger Plan 2020 (EPZA 2016; Clyde \& Co. 2014). The Plan was put in place to accelerate Tanzania's economic growth to between 8 per cent and 10 per cent by adopting the Asian Economic Development Model which focuses on employment creation through attracting FDI and export promotion by developing SEZs. Tanzania with the current population of 57.31 million, GDP of 52.09 billion USD majority of her population is peasant farmers.

Tanzania's gross domestic product advanced 6.8 percent year-on-year in the third quarter of 2017 , slowing from a 8.5 percent growth in previous period. Output rose less for agriculture ( 3.6 percent compared to 3.7 percent in Q2) and transport and storage (13.0 percent compared to 19.8 percent). Meanwhile, output increased faster for construction (11.1 percent compared to 8.8 percent); manufacturing (12.4 percent compared to 9.3 percent); mining and quarrying (20.8 percent compared to 18.0 percent); trade and repair (5.9 percent compared to 5.4 percent); water supply (19.1 percent compared to 7.0 percent) and information and communication (13.4 percent compared 12.3 percent). GDP Annual Growth Rate in Tanzania averaged 6.73 percent from 2002 until 2017, reaching an alltime high of 10.90 percent in the first quarter of 2007 and a record low of 2.60 percent in the third quarter of 2009. Moderate growth in agriculture and the poor performance of industry has meant that much of the African growth in the past decade came from the services sector. Comparing 1997 with 1980, the share of services within GDP rose from 38.7 to 48.6 per cent as shares of agriculture and industry declined from 22.3 to 19.5 per cent and from 39 to 31.9 per cent respectively. Such a steep decline in the share of industry at an early stage of industrialization and development suggests that the growth process in the region is highly fragile (UN 2001).

\section{Theory of poverty trapping in developing countries}

As discusses above, a lot of scholars has different theory regarding the underdevelopment and poverty trap of developing countries. The most prominent classical scholar that cherished by a lot of Afrocentric is Walter Rodney. Walter Rodney in how Europe underdeveloped Africa argued that, the question as to who and what is responsible for African underdevelopment can be answered in two levels. His argument based on blaming imperialism as a system. According to his argument, imperialism as a system drained African wealthy and made it impossible to develop the resources of the continent. Secondly one has to deal with those who manipulated the system and those who are either agents or unwitting accomplices of the said system. The capitalist of the western world were the ones who extended their exploitation from inside Europe to cover the whole of Africa. He concluded my arguing in recent times, they were joined, and some extent replaced, by the capitalists from the United States; and for many years now even the workers of the metropolitan countries have benefited from the exploitation system and underdevelopment of Africa. The argument is totally true in case of underdevelopment of Africa's economies, but why even after independence these least developing countries are still on poverty trapping? To answer the question a lot of scholars argues that the trapping of the imperialist system in still on the ongoing. African countries economies are still tied with their former exploiters economies. This kind of situation makes impossible for them to get rid of the trapping.

However there are some who argued different and provided whole set of evidences. Conducted the research, scientists led by Calistus Ngonghala, a mathematician at the University of Florida in Gainesville, collected both economic and disease data from 83 of the most and least developed countries. The data included annual income per person and the impact of diseases in terms of financial cost, disease incidence, and mortality, which vary dramatically around the world. For example, the caterpillar of the armyworm moth destroys crops in places like Brazil and Zimbabwe, but can't survive in places with temperate climates like Romania. Similarly, human diseases like malaria and dengue fever abound in places like Kenya, Tanzania and Cambodia, where the tropical climate favors their spread, and these countries also happen to offer limited access to health care. The researchers used these and related data to "train" mathematical models to determine how economic and disease factors, as well as ecological factors such as the growth rate of fish populations and other natural resources, affected poverty.

The models show that poor people who live in areas with limited human, animal, and crop disease might be able to lift themselves out of poverty either through their own means or with a bit of economic assistance, such as money to buy more crops and cattle. But in places of high disease and limited means of combating it, people could be stuck in poverty, no matter how much economic aid they receive, the team reports this month in Nature Ecology \& Evolution.

"If you're a subsistence farmer, infectious diseases not only affect your health, they also affect your earning, because you depend on your physical labor to get an income," Ngonghala says. "We were surprised when we realized that in some instances economic aid is not going to help at all."

Considering that more than $10 \%$ of the world, or about 800 million people-live in extreme poverty, the study suggests that most of them will never escape it unless issues beyond mere income are addressed.

One effective way to break poverty traps may be structural changes such as increasing access to health care 
by reducing health care costs, and preventing disease transmission through vaccine coverage. Once people are able to get well and safeguard their crops and livestock, they also might be able to dig themselves out of poverty, says study co-author Matthew Bonds, an economist at Harvard University.

Bonds uses as an example Rwanda, a sub-Saharan country that succeeded in reducing extreme poverty and hunger as part of the Millennium Development Goals, a series of international development goals for the year 2015. "[Rwanda] has had a major investment in health infrastructure and health systems," he says. "Most people can get access to health insurance and to most forms of health care inexpensively." In addition, foreign businesses are investing in the country's energy and telecommunication sectors, helping to lift people out of poverty traps, he says.

Recently, Rwanda is providing evidence as a success story for getting rid out of chronicle poverty trap. Rwanda's economy is taking off without the so called "democracy" and is becoming Africans shining light. The reason for the success however can be pointed out initially not because of massive foreign direct investments or economic aid. Rwanda itself first took initiative to set all necessary preconditions for taking off basing on the recourses it has.

\section{Conclusion}

Regardless the history some countries had but still escaped the trauma of economic and cultural imperialism and had a great leap. China provided as a good example of the newly and fast developing economy. Rwanda despite the traumatic experiences it faced in the 1990s is on the edge of taking off by taking initiatives and not depending of FDI.

This paper is neither trying to tell that Tanzania should copy what china and other NIC countries model of development, nor what Rwanda is doing to set the premises for taking off, rather its intended to provide the lesson from some countries who experienced same or even worse history and are getting rid of poverty trap.

What Tanzania should do is start by building markets through harnessing the institution it has. Tanzania should start with what it has which is weak institution with unlimited resources from agriculture, mining etc. When markets are built, these emerging markets would automatically stimulate strong institution like transparence, good governance "democracy" and so on, which in turn these strong institutions will preserve markets.

However Tanzania should also take its own initiative first on setting precondition for precondition or premises for development. Currently Tanzania initiated couple of industrial parks like what china did, but copying chine just initiating industrial parks out of the blue provides a baseless development. First in terms of infrastructures Tanzania still lags behind and electricity still unreliable. How can even industrial production carry on without reliable availability of electricity? Secondly there is uncoordinated economic (industrial and agricultural) policy. Recently Tanzania's government trying to promote local industries and agriculture by insisting on utilizing local produced and avoiding exporting of some agricultural products to neighboring countries which kills the local economy. I happened to meet of the owner of candy factory in Tanzania who was blaming Tanzania's government not allowing him to import sugar as raw material for his candy factory. The government requires him to buy local produced sugar which couldn't meet his factory needs on top of that most of time during production while machines still running there has been occasional power cut without prior notice upon power cut. For him Tanzania was not ready to initiate industrial parks.

Tanzania should pursue on coevolution by building markets with weak institution they have. Currently Tanzania has weak institution therefore it should not only build markets and forgets institutions. The two coevolve, as mentioned earlier that Poor countries possess abundant of so called weak institutions. Examples of weak institution in this article are government regulations, industrial promotion policies, incentives for petty fee extraction, campaign style, fusion of public and private interests and poverty eradications institutions. Normally a lot of scholars believe that to get out of poverty trap is just to replace such weak institution with the strong one like that on the west. What Tanzania is doing now initiating industrial parks is skipping stages, Tanzania should craw before it stands and start walking and running. It should start from the bottom by creating basic condition for small scale industrial development then FDI can boost it up.

In addition African countries includes Tanzania is not doing what it was doing the best in protecting the majority famers who are in poverty trap. These farmers were supposed to be supported in nurturing their livelihood but instead the government misdirecting the resources to industrial sector which in unprepared and not ready for it.

Robert Bates pointed out African countries failing to develop and get its majority people out of poverty trap because on bad economic policy that favor urban bureaucratic in three major pints; in describing this policies Bates pointed out government intervention that hindered agricultural development which is major export in Africa. The intervention are in market for agricultural commodities where government like discussed before control the market and determine who and where to sell, market for inputs of farming where a lot of inputs are directed to ailing industrial sector, and lastly markets for goods that farmers consume from urban and foreign industrial sector which are exploitative to favor profit maximization to favor local industrial which is ailing. 
These local Tanzania industrial which are favored by the government which obtained its funds from farmers by buying raw materials cheaply from farmers has increased poverty level in Tanzania. Example coffee growers in Tanzania were paid crop authority which acted as a government sponsored monopsony. At that time price of coffee in world market stood at Tsh 14.85 per kg in 1976 while local market the price was $6.32 \mathrm{~kg}$; farmers were obliged to sell to government monopsony. This kind of policy still on going to the present time, favoring local industrial in expenses of the majority farmers makes African countries stuck in poverty trap. Local initiative from farmers is important that can stimulate production and major investments on agricultural for export and industrial development. However industrial and agricultural policies should be revised to meet the condition for mutual agricultural and industrial development in Tanzania. Local initial mobilization is important to set precondition for development. Where these farmers can start develop on their own with favorable agricultural policy investments they can attract investments which will boost up economic developing and even more FDI.

If Tanzania will not unlock two economic factors which Tanzanians have been talking, Tanzania will never take off economically. About 60 to 70 percent of Tanzanians are farmers/ peasant farmers to be precise. These farmers are economic drivers of the dream for industrial initiation in everything in Tanzania. Tanzania is building infrastructure, industries etc. for transportation of goods and services but peasant produces both cash and food crops' prices are significantly dropping due to internal and external factors. The current president came with the dream of industrialization vision in Tanzania. When we talk about industrialization in Tanzania we cannot detach from agriculture. Agriculture is the back bone of Tanzania economy, and majority of export comes from agriculture. To develop industry and economy at whole, emphasize should be given to agricultural sector in link with industries. Diverting resources from agricultural to industries will never work

\section{References}

1. 1992. Tanzania Population Policy. Dar es Salaam: Presidents Office, The Planning Commission.

2. Abel Kinyondo,1 Carol Newman,2 and Finn Tarp3( 2016)The role and effectiveness of Special Economic Zones in Tanzania WIDER Working Paper 2016/122

3. Boserup, E. (1970). Women's Role in Economic Determinant. London: Allen and Unwin.

4. Brockerhoff M. (1995). The Labor-Market in Africa-Lachaud, JP Population and Development Review: 21 (2), 433.

5. Col. (Rtd) J. L. Simbakalia, R. Eng. (T) progress in industrial development- targets and goals, achievements, challenges and the way forward, working paper.

6. De Haas D. (2011).The Determinants of Internal Migration: Conceptualizing Policies, Origin and Destination Effects. Working Paper No.32, DEMIG Project Paper No.2, Department of Internal Development, International Migration Institute, Oxford: University of Oxford, 2011b

7. Fields, G,S. (1976). Lifetime Migration in Columbia: Test of The Expected Income Hypothesis. Population and Development Review, 5(2), 247-265.

8. Giorgia Guglielmi (2017)Why so much of the world is stuck in a 'poverty trap'

9. Honest Prosper Ngowi (2005) institutional reforms to attract foreign direct investments (FDIS) as a strategy for economic growth

10. Honest Prosper Ngowi (2009) Economic development and change in Tanzania since independence: The political leadership factor

11. HP Ngow i(2009) Economic development and change in Tanzania since independence: The political leadership factor

12. Peter Evans (1995) states and industrial transformation.

13. Peter Evans (1997) State-Society Synergy: Government and Social Capital in Development

14. Pun Ngai (2017) Class and Precarity - an Unhappy Coupling in China's Working Class Formation

15. Pun ngai (2005) made in china; women factory workers in china.

16. RH Bates - 2014Markets and states in tropical Africa: the political basis of agricultural policies

17. W Rodney(1972) - How Europe underdeveloped Africa

18. Yuen yuen ang (2016) how china escaped the poverty trap 